\title{
EKSISTENSI KEWENANGAN DAERAH DALAM PERLINDUNGAN DAN PENGELOLAAN LINGKUNGAN HIDUP PASCA DITERBITKANNYA UNDANG- UNDANG CIPTA KERJA
}

\author{
Ary Fatanen \\ Program Magister Ilmu Hukum, Universitas Muhammadiyah Yogyakarta, Indonesia \\ Email : aryfatanen86@gmail.com
}

\begin{abstract}
After the issuance of the Job Creation Law, which also regulates deleting, modifying, and making new arrangements for the provisions of articles in Law Number 32 of 2009 concerning Environmental Protection and Management which affect regional authority autonomously in implementing business licenses of course it needs to be implemented with due regard to environmental impacts. The research method used is a qualitative legal material analysis method with a statutory approach method. Collecting data by reviewing statutory regulations, theory and literature review supported by the opinions of related experts, namely experts with expertise in their fields. The purpose of this research is to study and analyze the regional government authority in protecting and managing the environment after the enactment of the Job Creation Law, which regulates changes to the Environmental Law on the substance of environmental approval.
\end{abstract}

Keywords: Authority, Local Government, Environment

\begin{abstract}
ABSTRAK
Pasca diterbitkannya UU Cipta Kerja yang di dalamnya juga mengatur terkait menghapus, merubah, dan melakukan pengaturan baru terhadap ketentuan pasal dalam UU No.32 Tahun 2009 tentang Perlindungan dan Pengelolaan Lingkungan Hidup (UUPPLH) yang mempengaruhi terhadap kewenangan daerah secara otonom dalam melaksanakan perijinan usaha yang tentu perlu dilaksanakan dengan memperhatian dampak lingkungan. Motode penelitian menggunakan metode analisis bahan hukum kualitatif dengan metode pendekatan perundang-undangan. Pengumpulan data dengan cara mengkaji peraturan perundang-undangan, teori serta telaah pustakan yang didukung dengan pendapat para ahli terkait yaitu ahli yang berkopeten dibidangnya. Tujuanya penelitian ini untuk mengkaji dan menganalisis tentang kewengan Pemerintah Daerah dalam melakukan perlindungan dan pengelolaan lingkungan hidup pasca ditertapkannya Undang-Undang Cipta Kerja yang di dalamnya mengatur perubahan UU Lingkungan pada substansi persetujuan lingkungan.
\end{abstract}

Kata Kunci: Kewenangan, Pemerintah Daerah, Lingkungan

\section{PENDAHULUAN}

Pelaksanaan otonomi daerah hari ini memberikan kewenangan yang lebih besar terhadap daerah untuk mengurus wilayahnya sendiri secara mandiri (Hariyanto, 2020). Tujuannya dalam sisi lingkungan, pemerintah daerah bisa lebih dekat kepada hubungan masyarakat dengan lingkungan. Kewenangannya adalah Pemerintah daerah provinsi, daerah Kabupaten, dan Kota mengatur dan mengurus sendiri urusan pemerintahan menurut asas otonomi dan tugas pembantuan (Pasal 18 ayat (2) Undang-Undang Dasar

* Copyright (c) 2021 Ary Fatanen

This work is licensed under a Creative Commons Attribution-ShareAlike 4.0 International License. 
Khazanah Hukum, Vol. 3 No. 1: 1 - 7

Eksistensi Kewenangan Daerah dalam Perlindungan dan Pengelolaan Lingkungan Hidup Pasca diterbitkannya Undang-Undang Cipta Kerja

Ary Fatanen

1945), baik otonomi maupun tugas pembantuan sama-sama mengandung kebebasan dan kemandirian, perbedaannya hanya pada tingkat kebebasan dan kemandirian (Susanto, 2015).

Diterapkan pada konsep hukum lingkungan, otonomi daerah memilki peran sangat penting terutama dalam hal mengatur wilayah secara mandiri berdasarkan karakteristik lingkungan hidupnya masing-masing (Suharjono, 2014). Karakteristik lingkungan hidup satu wilayah dengan wilayah lain tentu memiiki perbedaan terutama pada segi geografisnya. Otonomi daerah memiliki kaitan erat dengan karakteristik pembangunan, yang menjadi parameter akan pembangunan berkelanjutan. Sifat keterkaitan (interdependensi) dan keseluruhan (holistik) dari esensi lingkungan telah membawa konsekuensi bahwa pengelolaan lingkungan, termasuk sistem pendukungnya tidak dapat berdiri sendiri, akan tetapi terintegrasikan dan menjadi roh dan bersenyawa dengan seluruh pelaksanaan pembangunan sektor dan daerah (Sabardi, 2014). Dalam perlindungan dan pengelolaan lingkungan hidup, Pemerintah Daerah memiliki kewenangan secara hak dan kewajiban yang ditur dalam UUPPLH terutama pada sisi yuridis administrasi (Sutrisno, 2013). Dokumen Lingkungan, Izin Lingkungan, dan administrasi lain berdasarkan kewenangan daerah yang menjadi obyek kewenangan dalam perlindungan dan pengelolaan lingkungan hidup.

Belum lama ini sekitar tanggal 5 Oktober 2020 Dewan Perwakilan Rakyat baru saja mengesahkan UU Cipta Kerja yang Undang Undang tersebut menggunkan metode penyusunan omnibus law, dengan menggabungkan beberapa pengaturan tingkat Undang-Undang menjadi satu. Salah satu Undang-Undang yang masuk di dalam substansi pengaturan UU Tentang Cipta Kerja adalah UUPPLH. UUPPLH masuk dalam Paragraf 3 Pasal 21 dan Pasal 22, yang di dalamnya secara langsung menjelaskan terkait mengubah, menghapus, atau menetapkan pengaturan baru beberapa ketentuan terkait Perizinan Berusaha yang diatur dalam UUPPLH. Beberapa penelitian terdahalu mengalami kekosongan pada penelitian ini kebanyakan penelitian yang telah di kaji mengenai dampak omibus law dan lebih focus pada pasal - pasal mengenai dunia kerja (Darmawan, 2020; Orinaldi, 2020; Suryokumoro \& Ula, 2020). Oleh karena itu penelitian ini mencoba mengisi kekosongan kajian terhadap dampak dari omnibus law pada kekuatan pemerintah menjaga lingkungannya dikarenakan Omnibuslaw juga mengatur masalah lingkungan, Berdasarkan perubahan inilah akan diamati terkait eksistensi kewenangan daerah pasca disahkannya undang-undang tentang Cipta Kerja tersebut.

\section{METODE PENELITIAN}

Jenis penelitian ini kategori termasuk penelitian hukum normatif. Penelitian hukum normatif adalah penelitian hukum yang dilakukan dengan cara meneliti bahan pustaka atau sekunder (Rahayu et al., 2020). Bahan hukum sekunder dalam penelitian hukum normatif berupa penelitian kepustakaan (library research). Pendekatan yang digunakan adalah konsep pendekatan undang-undang (statute approach) dilakukan dengan menelaah semua undang-undang dan regulasi yang bersangkut paut dengan isu hukum yang sedang ditangani (Marzuki, 2015). Penelitian kepustakaan ini digunakan untuk memperoleh bahan-bahan berupa dokumen hukum, baik yang berupa Peraturan perundang-undangan, Peraturan Pemerintah, Keputusan/Peraturan, Yurisprudensi, jurnal-jurnal, Hasil Penelitian, Publikasi ilmiah dan buku-buku yang berkaitan dengan pokok permasalahan yang diteliti dan tentu dilakukan diperkaya dengan data-data lapangan. 
Khazanah Hukum, Vol. 3 No. 1: 1 - 7

Eksistensi Kewenangan Daerah dalam Perlindungan dan Pengelolaan Lingkungan Hidup Pasca diterbitkannya Undang-Undang Cipta Kerja

Ary Fatanen

\section{HASIL DAN PEMBAHASAN}

\section{Implementasi Otonomi Daerah}

Dengan adanya UU Pemerintah Daerah (UU No. 23 Tahun 2014), menjadi dasar pengaturan otonomi Pemeintah Daerah yang secara konkrit dijelaskan mengenai hak dan kewajiban Pemerintah Daerah beserta pengaturannya. Lingkungan Hidup termasuk ke dalam rumpun urusan Pemerintahan wajib yang tidak berkaitan dengan pelayanan dasar, sesuai dengan Pasal 12 ayat (2) huruf (e). Kunci dalam otonomi daerah sebagai perlindungan dan pengelolaan lingkungan hidup adalah pada situasi karakteriristik lingkungan di masing-masing wilayah kewenangan, karena sejatinya kondisi lingkungan memiliki tipikal secara unik yang masing-masing wilayah perlu perlakuan khusus dalam mengeksplorenya. Pelaksanaan otonomi daerah menjadi tidak seimbang sebagaimana daerah akan membangun dengan tetap memperhatikan keunggulan dan ciri khas masing-masing daerah otonom (Kholid et al., 2018). Mendasari hal ini maka adanya kewenangan daerah untuk mengatur daerah sendiri menunjukan bahwa daerah tersebut bisa menentukan arah pembangunan sesuai dengan kebutuhan daerah tersebut.

Otonomi Daerah secara mendasar berkaitan dengan hak, wewenang dan kewajiban daerah untuk mengatur dan mengurus rumah tangganya sendiri. Hak tersebut diperoleh melalui penyerahan urusan pemerintah dari pemerintah pusat kepada pemerintah daerah sesuai dengan keadaan dan kemampuan daerah yang bersangkutan (Wijayanti, 2017). Konsep otonomi daerah sebenarnya adalah konsep yang bertujuan mendekatkan pemerintah daerah dengan masyarakat, sehingga pemerintah daerah dalam hal pembangunan mampu mengakomodir permasalahan-permasalahan yang akan dihadapi masyarakat.

Masalah Otonomi Daerah berkaitan erat dengan pembagian kekuasaan pemerintah pusat dan pemerintah daerah. Artinya hubungan mendasar antara pemerintah pusat dan pmerintah daerah secara kebijakan adalah berjenjang atau upbottom. Oleh karena itu pendelegasian wewenang antara pemerintah pusat dengan pemerintah daerah harus diatur secara sistematis, sehingga akan memudahkan dalam sisi pembinaan dan pengendalian.

Pengambilan keputusan dalam konsep otonomi daerah secara ideal akan lebih teliti melihat kepada sisi local wisdom, sehingga pemerintah daerah dalam melakukan pengambilan keputusan akan lebih teliti khsususnya pada sisi kebutuhan masyarakat. Ada tiga bentuk kegiatan pengambilan keputusan yang dapat dibedakan dengan penggunaan istilah "peraturan", "keputusan/ketetapan" dan "tetapan", menurut Jimly istilah-istilah tersebut sebaiknya hanya digunakan untuk (Assiddiqie, 2014):

1. Istilah "peraturan" digunakan untuk menyebut hasil kegiatan pengaturan yang menghasilkan peraturan (regels).

2. Istilah "keputusan" atau "ketetapan" digunakan untuk menyebut hasil kegiatan penetapan atau pengambilan keputusan administratif (beschikkings).

3. Istilah "tetapan" digunakan untuk menyebut penghakiman atau pengadilan yang menghasilkan putusan (vonnis).

Dalam pemerintah daerah, peraturan (regels) yaitu berbentuk peraturan daerah, peraturan gubernur pada tingkat provinsi, peraturan walikota/bupati pada tingkat kota/kabupaten. Lalu keputusan atau ketetapan (beschikkings) kepala daerah Gubernur/Bupati/Walikota. Kedua hal tersebutlah yang selalu melekat di dalam kewenangan pemerintah daerah, karena kedua hal tersebut harus identik dengan kewilayahan. 
Khazanah Hukum, Vol. 3 No. 1: 1 - 7

Eksistensi Kewenangan Daerah dalam Perlindungan dan Pengelolaan Lingkungan Hidup Pasca diterbitkannya Undang-Undang Cipta Kerja

Ary Fatanen

\section{Kewenangan Pemerintah Daerah Dalam Perlindungan Dan Pengelolaan Lingkungan Hidup Berdasarkan UUPPLH}

Membahas terkait kewenangan pemerintah daerah dalam perlindungan dan pengelolaan lingkungan hidup berarti secara yuridis yang termaktub dalam UU Pemerintah Daerah (Nomor 23 Tahun 2014) yang di dalamnya secara langsung memberikan kewenangan dalam hal urusan terkait lingkungan hidup. Ada setidaknya 11 (sebelas) Sub bidang (Lampiran huruf K, Undang-Undang Pemerintah Daerah):

1. Perencanaan Lingkungan Hidup;

2. Kajian Lingkungan Hidup Strategis(KLHS);

3. Pengendalian Pencemaran dan/atau Kerusakan Lingkungan Hidup;

4. Keanekaragaman Hayati (Kehati);

5. Bahan Berbahaya dan Beracun (B3), dan Limbah Bahan Berbahaya dan Beracun (Limbah B3);

6. Pembinaan dan pengawasan terhadap izin lingkungan dan izin perlindungan dan pengelolaan lingkungan hidup (PPLH);

7. Pengakuan keberadaan masyarakat hukum adat (MHA), kearifan lokal dan hak MHA yang terkait dengan PPLH;

8. Pendidikan, Pelatihan, dan Penyuluhan Lingkungan Hidup Untuk Masyarakat;

9. Penghargaan Lingkungan Hidup Untuk Masyarakat;

10. Pengaduan Lingkungan Hidup; dan

11. Persampahan.

Kewenangan pemerintah daerah dalam hal lingkungan hidup diatas bersumber dari (Pasal 63 ayat (2) dan ayat (3), UUPPLH), yang Pasal tersebut memberikan amanat dalam hal tugas dan tanggungjawab kepada Daerah, agar mampu menentukan tipe atau model pendekatan pembangunan apa yang harus digunakan dalam wilayahnya yang mendasarkan akan keberlangsungan lingkungan hidup sesuai pengaturannya.

Baerdsarkan tugas dan tanggungjawab tersebut dalam perjalan pelaksanaan otonomi daerah dalam bidang lingkungan ternyata terdapat kecemasan dalam menjalankan otonomi khususnya dalam bidang lingkungan yaitu (Husin, 2009):

1. Adanya kecenderungan bahwa Pemerintah Daerah mengejar Pendapatan Asli Daerah, maka penyelematan lingkungan terabaikan.

2. Pemerintah Daerah tidak siap dengan SDM untuk melakukan pengelolaan lingkungan guna menciptkan pembangunan yang berkelanjutan.

Kecemasan ini relevan ketika pelaksanaan otonomi daerah menjadi hal yang baru pada waktu itu, namun harapan adanya otonomi daerah juga tidak bisa memberikan solusi dalam pembangunan, sehingga hal ini oleh pemerintah pusat menjadi kendala dalam menentukan arah ekonomi negara, karena masih banyak otonomi yang digulirkan ternyata tidak berjalan dengan semestinya, maka dengan adanya undang-undang cipta kerja ini menjawab permasalahan ini, namun demikian permasalahan ini menjadi tidak bisa memberikan perlindungan terhadap rakyat yang ada di daerah melalui kepala daerah yang dipilih setiap lima tahun dalam menentukan pembanungan dan pengelolaan kekayaan alam, karena ketika kepala daerah ingin menentukan kebijkan yang tidak sesuai dengan kebijakan pemerintah pusat maka kebijakan tersebut akan di anulir oleh pemerintah pusat sehingga muncul desentrlisasi kekuasaan dalam pembangunan. 
Khazanah Hukum, Vol. 3 No. 1: 1 - 7

Eksistensi Kewenangan Daerah dalam Perlindungan dan Pengelolaan Lingkungan Hidup Pasca diterbitkannya Undang-Undang Cipta Kerja

Ary Fatanen

\section{Kewenangan Pemerintah Daerah Dalam Perlindungan dan Pengelolaan Lingkungan Hidup Pasca Undang-Undang Cipta Kerja}

Pemerintah melalui Dewan Perwakilan Rakyat telah mengesahkan omnibus law Undang-Undang (UU) Cipta Kerja pada 5 Oktober 2020. Yang di dalamnya juga memuat pengaturan terkait perubahan UUPPLH (Muqsith, 2020). UUPPLH masuk kedalam substansi pengaturan pada Paragraf 3 Pasal 21 dan Pasal 22 UU Cipta Kerja. Secara substansi ternyata ketentuan dalam UUPPLH banyak yang dirubah dan dihapus, terutama pada hal kewenangan Pemerintah Daerah. Poin pokok kewennagan Daerah yang berubah adalah:

1. Pasal 22 angka 3 UU Cipta Kerja merubah ketentuan Pasal 24 UUPPLH yang menjelaskan terkait teknis dalam Uji Kelayakan Lingkungan Hidup dilakukan oleh Tim Uji yang dibentuk Pemerintah Pusat. Berdasarkan hal tersebut berarti Pemerintah Daerah tidak memiliki kewenangan dalam membentuk Tim Uji, sehingga unsur tim lebih dominan terhadap unsur Pemerintah Pusat meskipun unsur Pemerintah Daerah termasuk dalam Tim Uji. Pasal ini mempengaruhi Pasal selanjutnya yang dalam UU Cipta Kerja

2. Pasal 22 angka 8 sampai angka 10 UU Cipta Kerja yang menghapus ketentuan Pasal 29 sampai dengan Pasal 31 UUPPLH yang secara substansi mengatur tentang Komisi Penilaian Amdal. Dengan dihapusnya Komsisi Penilaian Amdal yang disederhanakan dengan tahapan Uji Kelayakan Lingkungan yang Tim Uji nya dibentuk oleh Pemerintah Pusat, Pemerintah Daerah kehilangan kewenangan dalam menentukan kebijakan tersebut.

3. Pasal 22 angka 12 UU Cipta Kerja merubah ketentuan Pasal 34 UUPPLH yang secara substansi menghilangkan kewenangan dalam menentukan suatu kewenwngan bagi Pemerintah Daerah dalam kebijakan dalam hal menentukan bentuk usaha atau kegiatan yang wajib dilengkapi UKL UPL, karena kewnenangan tersebut menjadi kewenangan Pemerintah Pusat.

4. Pasal 22 angka 17 UU Cipta Kerja merubah ketentuan Pasal 39 UUPPLH secara substansi merubah cara dalam memberikan pengumuman terhadap Keputusan Kelayakan Lingkungan yang cara tersebut ditentukan oleh Pemerintah Pusat.

5. Pasal 22 angka 19 UU Cipta Kerja merubah ketentuan Pasal 55 UUPPLH secara substansi kewenangan Pemerintah Daerah dalam menentukan Bank Pemerintah dalam hal dana penjamin pemulihan fungsi lingkungan hidup dan menetapkan pihak ketiga yang melakukan pemulihan fungsi lingkungan hidup yang secara kewenangan ditegaskan menjadi kewenangan Pemerintah Pusat.

6. Pasal 22 angka 23 UU Cipta Kerja merubah ketentuan Pasal 63 UUPPLH yang secara tegas merubah ketentuan kewennagan Pemerintah Daerah dalam menentukan kebijakan Pemerintah Daerah dalam menetapkan kebijakan terkait Amdal dan UKL-UPL, Pemerintah Daerah hanya diberikan wewenang untuk melaksanakan kebijakan saja dalam hal tersebut.

Melihat pada uraian tabel diatas, sebenarnya secara karakteristik unsur dominasi kewenangan ada pada Kewenangan Pusat, yang jelas menghilangkan policical will Pemerintah Daerah. Kewenangankewenangan tersebut merupakan kewenangan-kewenangan strategis, yang wilayah kewnenangan tersebut sebenarnya syarat dengan karakteristik Daerah. Pola pemilahan kewenangan dalam pengaturan UU Cipta Kerja ini adalah pola sentralistik yang model tersebut Pemerintah Pusat menjadi lebih dominan. Substansi pengaturan UUPPLH di dalam UU Cipta Kerja sebenarnya sudah mencederai unsur pembentukan UUPPLH itu sendiri, yang bisa dilihat dalam unsur menimbang dalam pembentukan 
Khazanah Hukum, Vol. 3 No. 1: 1 - 7

Eksistensi Kewenangan Daerah dalam Perlindungan dan Pengelolaan Lingkungan Hidup Pasca diterbitkannya Undang-Undang Cipta Kerja

Ary Fatanen

UUPPLH tersebut dalam huruf $\mathrm{c}$ semangat otonomi daerah menjadi salah satu unsur dasar pembentukannya.

Kewenangan-kewenangan yang ditegaskan menjadi kewenenangan Pemerintah Pusat, merupakan dasar fundamental secara yuridis administrasi yang syarat dengan karakteristik wilayah, yang hal tersebut syarat dengan kebijakan kewilayahan. Lingkungan satu dengan lingkungan lain memiliki potensi dan kelemahan masing-masing yang memerlukan sentuhan campur tangan Pemerintah Daerah untuk dapat menentukan, melaksanakan, dan mengawasi pembangunan dapat berkelanjutan.

\section{Pudarnya Semangat Otonomi Daerah Dalam Perlindungan Dan Pengelolaan Lingkungan}

Problematika yang telah dijabarkan diatas secara nyata bertentangan dengan konsep pembangunan yang dilaksanakan dengan model otonomi daerah, karena makna otonom adalah tatanan yang bersangkutan dengan cara membagi wewenang, tugas dan tanggungjawab mengatur dan mengurus urusan pemerintah antara pusat dan daerah (Said, 2015). Pembagian kewenangan ini pada prinsip dilaksanakan untuk dapat memajukan daerah tersebut dengan tetap memperhatikan keadaan yang ada khususnya terhadap lingkungan. Jika mengacu dari sini berdasarkan kelembagaan terkait Pengolaan Lingkungan terdapat beberapa kelembagaan yang terkait yaitu Kementrian Lingkungan Hidup, Kementrian Sektoral dan Lembaga pemerintah Non Kemetrian serta Kelembagaan Pengelolaan Lingkungan di Daerah.

Berbicara tentang kelembagaan diatas berarti berbicara tentang tanggungjawab terhadap pemeliharaan negara dengan lingkungan, maka terkait dengan kelembagaan lingkungan yang ada di daerah pada intinya di kelola dengan kelembagaan pengelolaan lingkungan di daerah. Kelembagaan lingkungan di daerah ini sejak berlakukanya Keputusan Presiden Nomor 77 Tahun 1994 tentang Badan Pengendalian Dampak Lingkungan di daerah dapat dibentuk Bapedal Daerah dan ketentuan ini bersifat wajib sehingga pemebentukan ini diserahkan kepada kemampuan dan kemauan Daerah (Akib, 2014). Kekuatan dan keberimbangan daerah inilah yang seharusnya di dorong oleh pemerintah pusat melalui otonomi daerah dalam menjalankan perlindungan terhadap lingkungan hidup bukan memanfaatkan pembangunan untuk kepentingan politik ekonomi sesaat sehingga kehidupan manusia yang seharus dapat hidup berdampingan dengan alam karena adanya kebijakan pembangunan melalui undang-undang cipta kerja membentuk monopoli baru dalam pembagian kewenangan daerah untuk menjaga alam serta pemetaan pembangunan yang tidak ramah lingkungan akan berdampak pada masyarakat. Sehingga nilai otonomi daerah dalam bidang lingkungan hidup tidak bisa menciptkana nilai nilai yang terkandung dalam sila ke 2 yaitu "Kemanusian yang Adil dan Beradab.

\section{SIMPULAN}

Berdasar pembahasan diatas maka dapat diambil kesimpulan bahwa adanya undang-undang cipta kerja telah mengambil alih kewenangan daerah untuk mmenetapkan kebijakan mengenai Amdal dan UKL-UPL sehingga mengakibatkan degradasi kewenangan daerah yang berpotensi kepada kebijakan Pemeintah Pusat yang tidak sesuai karakteristik wilayah. Tindakan ini jelas tidak bisa dipungkiri bahwa kewenangan Pemerintah Pusat dalam menjalan pembangunan hari ini tentu berorientasi pada ekonomi tanpa melihat keadaan alam dimasa yang akan datang, sehingga berpotensi memberikan dampak yang tidak bisa diduga karena akibat pembangunan industri. 
Khazanah Hukum, Vol. 3 No. 1: 1 - 7

Eksistensi Kewenangan Daerah dalam Perlindungan dan Pengelolaan Lingkungan Hidup Pasca diterbitkannya Undang-Undang Cipta Kerja

Ary Fatanen

Keberadaan undang-undang cipta kerja sama saja memangkas kewenangan daerah dalam menerapkan sistem otonomi daerah dengan harapan pemerintah daerah yang mengetahui keberdaan dan kondisi daerahnya jika kewenangan tersebut bertentangan dengan pembangunan dalam menciptkan lapangan kerja, maka kebijakan pemerintah daerah dapat dianulir atau dihilangkan, padahal kedudukan dan pemerintah daerah dan pusat dalam sistem demokrasi kedudukannya sama. Kesamaan ini dikarekan kekuasaan yang didapat oleh Pemerintah Pusat dan Daerah sama-sam dari pemilihan langsung sehingga jika saling menangan dalam memakmurkan rakyat hal ini yang harus dibenahi melalui kordinasi kebijakan yang dapat mensejahterakan rakyat.

\section{DAFTAR PUSTAKA}

Akib, M. (2014). Hukum Lingkungan Perspektif Global dan Nasional. Jakarta: Raja Grafindo Persada. Assiddiqie, J. (2014). Perihal Undang-Undang (3rd ed.). RajaGrafindo.

Darmawan, A. (2020). Politik Hukum Omnibus Law dalam Konteks Pembangunan Ekonomi Indonesia. Indonesian Journal of Law and Policy Studies, 1(1), 13-24.

Hariyanto, H. (2020). Hubungan Kewenangan antara Pemerintah Pusat dan Pemerintah Daerah Berdasarkan Negara Kesatuan Republik Indonesia. Volksgeist: Jurnal Ilmu Hukum Dan Konstitusi, 3(2).

Husin, S. (2009). Penegakan Hukum Lingkungan Indonesia. Sinar Grafika.

Kholid, F. N., Harjiyatni, F. R., \& Wardani, S. H. R. (2018). The Decree Of Cancellation Of The Minister of The Republic of Indonesia And The Implication of Authorityregional People's Representative Assembly.

Marzuki, P. M. (2015). Penelitian Hukum. Surabaya: Kencana Prenada Media Group. Putusan Pengadilan Militer II-11 Yogyakarta Nomor 78-K. PM II-11/AD/X.

Muqsith, M. A. (2020). UU Omnibus law yang Kontroversial. 'ADALAH, 4(3).

Orinaldi, M. (2020). Relasi Antara Omnibus Law di Era Pandemi Covid-19 Dan Perekonomian di Indonesia. J-MAS (Jurnal Manajemen Dan Sains), 5(2), 269-275.

Rahayu, D. P., SH, M. H., \& Ke, S. (2020). Metode Penelitian Hukum. Yogyakarta: Thafa Media.

Sabardi, L. (2014). Peran serta masyarakat dalam pengelolaan lingkungan hidup menurut Undangundang Nomor 32 Tahun 2009 tentang Perlindungan dan pengelolaan lingkungan hidup. Yustisia, FH UNS Edisi, 88.

Said, A. R. A. (2015). Pembagian kewenangan pemerintah pusat-pemerintah daerah dalam otonomi seluas-luasnya menurut UUD 1945. Fiat Justisia: Jurnal Ilmu Hukum, 9(4).

Suharjono, M. (2014). Pembentukan Peraturan Daerah Yang Responsif Dalam Mendukung Otonomi Daerah. DiH: Jurnal Ilmu Hukum, 10(19).

Suryokumoro, H., \& Ula, H. (2020). Menelaah Koperasi Era Omnibus Law. Mulawarman Law Review, $80-95$.

Susanto, M. (2015). Book Review: Perjalanan Historis Pasal 18 UUD 1945 (Perumusan dan UndangUndang Pelaksanaannya). Padjadjaran Journal of Law, 2(3), 620-625.

Sutrisno, B. (2013). Kerancuan Yuridis Kewenangan Perlindungan Dan Pengelolaan Lingkungan Hidup Dalam Perspektif Otonomi Daerah. DiH: Jurnal Ilmu Hukum, 9(17).

Wijayanti, S. N. (2017). Hubungan Antara Pusat dan Daerah Dalam Negara Kesatuan Republik Indonesia Berdasarkan Undang-Undang Nomor 23 Tahun 2014. Jurnal Media Hukum, 23(2), 186-199. 